\title{
QUALITY OF SLEEP OF THE AGED AT HOME AND IN HOSPITAL ${ }^{1}$
}

\author{
Natália Tonon Monteiro², Maria Filomena Ceolim³
}

${ }^{1}$ Excerpt from the scientific initiation study entitled -“A qualidade do sono dos idosos no domicílio e na hospitalização”, financed by
PIBIC/CNPq and completed in July of 2012.
${ }^{2}$ Nursing undergraduate student of the Nursing School of the State University of Campinas (Unicamp). São Paulo, Brazil.
E-mail: nataliat.monteiro@gmail.com
${ }^{3}$ Ph.D. in Nursing. Associate Professor of the Nursing School of Unicamp. São Paulo, Brazil. E-mail: fceolim@fcm.unicamp.br

ABSTRACT: The objective of this study was to describe the quality of sleep of aged individuals at home and in hospital. Descriptive study, conducted in the wards of a university hospital in São Paulo, Brazil, with 160 individuals (57.5\% men, mean age 69.8 years) admitted for a period between 48 hours to five days, who were able to answer the instruments. The Pittsburgh Sleep Quality Index was used at home and a visual analog scale of sleep in the hospital. This scale indicated satisfactory sleep quality and moderate daytime sleepiness. The Pittsburgh Sleep Quality Index indicated poor quality of sleep at home (69.4\%), more particularly sleep fragmentation for the majority of subjects. Data indicating poor quality of sleep at home emphasize the need for assessing the quality of sleep of the elderly, especially its fragmentation, as well as the need for studies that give support to practices that promote good sleep quality during hospitalization, aiming at clinical recovery.

KEYWORDS: Aged. Sleep. Nursing.

\section{QUALIDADE DO SONO DE IDOSOS NO DOMICÍLIO E NA HOSPITALIZAÇÃO}

RESUMO: O objetivo deste trabalho foi descrever a qualidade do sono de idosos no domicílio e na hospitalização. Estudo descritivo e exploratório, conduzido em enfermarias de um hospital universitário do interior de São Paulo, com 160 idosos (57,5\% homens; média de 69,8 anos) internados de 48 horas a cinco dias, capazes de responder aos instrumentos. Utilizaram-se o Índice de Qualidade de Sono de Pittsburgh para o domicílio e a Escalas Visuais Análogas de Sono para a hospitalização. Esta escala indicou sono de qualidade satisfatória e sonolência diurna moderada, majoritariamente. O Índice de Qualidade de Sono de Pittsburgh indicou sono de má qualidade no domicílio $(69,4 \%)$, destacando-se a fragmentação. Os dados indicando sono de má qualidade no domicílio enfatizam a necessidade de avaliar o sono do idoso, principalmente sua fragmentação, bem como necessidade de estudos que subsidiem práticas que favoreçam o sono de boa qualidade na hospitalização, visando a recuperação clínica.

PALAVRAS CHAVE: Idoso. Sono. Enfermagem.

\section{CALIDAD DEL SUEÑO DE LOS ANCIANOS EN EL HOGAR Y EN EL HOSPITAL}

RESUMEN: El objetivo de este estudio fue describir la calidad del sueño de los ancianos en el hogar y en el hospital. Estudio descriptivo, realizado en un hospital universitario de São Paulo, Brasil, con 160 personas (57,5\% hombres, edad media 69,8 años) ingresados de 48 horas a cinco días, capaces de responder los instrumentos. Se utilizó el Índice de Calidad del Sueño de Pittsburgh para el hogar y una escala visual analógica de sueño en la hospitalización. Esta escala indicó que la calidad del sueño era satisfactoria y de la somnolencia diurna de satisfactorias y moderadas, mayoritariamente. El Índice de Calidad del Sueño de Pittsburgh indicó sueño de mala calidad en el hogar $(69,4 \%)$, destacándose la fragmentación. Los datos que indican la falta de sueño en el hogar destacan la necesidad de evaluar el sueño en los ancianos, especialmente su fragmentación, así como de estudios que apoyen prácticas que promueven sueño de buena calidad durante la hospitalización, con miras a la recuperación clínica.

PALABRAS CLAVE: Anciano. Sueño. Enfermería. 


\section{INTRODUCTION}

The Brazilian population is growing old, with 21 million aged people (60 years old and over) in 2009, with an increase in the percentage of aged people from $9.1 \%$ to $11.3 \%$ between 1999 and $2009 .{ }^{1}$ Physiologically, aging results from continuing and irreversible changes that lead to a gradual loss of functions and homeostasis. ${ }^{2-3}$

Among these changes, we can mention sleep, which becomes lighter and more fragmented, and therefore, less efficient and poorer in quality. ${ }^{4}$

For this reason, it is important to observe other sleep changes in the aged, as the constant difficulty to sleep can increase the risks of falling, cognitive damages, loss of respiratory and cardiovascular function, mortality and need for nursing care. ${ }^{4}$

Some situations can result in sleep pattern changes, such as hospitalization and its consequences: procedures of the nursing staff, also during the night, and the change of environment, sometimes with more noise and light, resulting in sleep deprivation and increased fragmentation. ${ }^{4}$

Hospitalization can be more frequent with advancing age due to an increased risk of developing chronic diseases as population grows old. Studies show that $53.3 \%$ of aged people in Brazil are hypertensive and $2.5 \%$ have neoplasms. ${ }^{1}$

Sleep is essential for recovery in situations of illness and to prevent other diseases, as the immune system and humoral immunity are regulated during sleep. ${ }^{5}$

In the nursing process, it is the responsibility of the nurse to assess the quality of sleep and the possible sleep disorders of the patient, taking actions to improve their sleep, which will consequently contribute to a clinical improvement.

NANDA International proposes the following diagnoses that can be identified by the nurse concerning sleep/rest, from data collection and clinical judgment: "Insomnia, Disturbed sleep pattern, Sleep deprivation and Mood for improved sleep" ${ }^{6}$

It is also possible to obtain information on quality of sleep of patients through the use of instruments such as questionnaires used to assess sleep patterns, which can help the nurse make a diagnosis.

Among the available instruments, there is the Pittsburgh Sleep Quality Index (PSQI), which is used to assess the quality of sleep of an adult for the last 30 days, allowing to evaluate the features and usual sleep disorders. ${ }^{7}$ This instrument is validated for use in Brazil. ${ }^{8}$ Another instrument is the Verran and Snyder-Halpern Sleep Scale (VSH), ${ }^{10}$ which is also valid in Brazil. ${ }^{9}$ It analyzes the sleep for 24 hours in a subjective manner and is used with hospitalized patients. ${ }^{10}$

There is a small number of studies in this field, despite its importance. The sleep of the aged must be given special attention, as it is already disturbed by physiological changes. The nurse must be aware of the sleep patterns of the aged person in order to be ready to face possible negative effects resulting from poor sleep quality during hospitalization.

With the help of the aforementioned instruments, it is possible to assess the quality of sleep of the aged at home and in hospital, checking the regular sleep pattern and possible changes related to hospitalization. These findings can provide resources to make diagnoses and therefore intervene according to the specific needs of patients.

The aim of this study was to characterize the quality of sleep of aged people before and during hospitalization.

\section{METHOD}

This is a descriptive, quantitative and crosssectional study. The research was carried out in clinical and surgical wards of a university hospital in the countryside of the state of São Paulo. The individuals surveyed were 160 aged people (60 years old and over), who had been hospitalized for at least 48 hours and up to five days and who were clinically and psychologically able to answer the questionnaires. The exclusion criteria were: no sensitivity to light, to have been hospitalized where the study was carried out or in another hospital less than one month before; not meeting the researcher in the ward twice. The number of individuals was defined according to the duration of data collection, which was initially of four months, as it was projected to interview an average of four people per day, three days a week. As this rate was not reached by the end of the fourth month, the collection was extended to seven months.

Three instruments were used: the Sociodemographic and Clinical Questionnaire, the PSQI and the VSH. The Sociodemographic and Clinical Questionnaire is semi-structured and was created 
by the researchers specially for this study, aiming to identify the aged person by collecting personal information, their clinical history and their socioeconomic conditions. Besides, there is a question on factors that have an effect on sleep at home. The PSQI was used to assess the quality of sleep of the elderly at home, as it covers a period of 30 days. It evaluates seven elements: subjective quality of sleep (question 6); sleep onset latency (questions 2 and 5a); duration of sleep (question 4 ); usual sleep efficiency (relation between duration of sleep reported by the patient) and duration of sleep calculated by the difference between the wake up time and bed time reported in questions 1 and 3 respectively. This number is expressed in percentage and can be over $100 \%$, should the patient report a longer duration of sleep than the calculated value of time in bed); sleep disorders (questions $5 \mathrm{~b}$ and $5 \mathrm{j}$ ); use of sleep medicine (question 7); and daytime sleepiness (questions 8 and 9). Each component is given a score between zero and three, and the scale total corresponds to the sum of the components and ranges from zero to 21 points. The higher the final score the poorer the quality of sleep, so if the final score is over five, the quality of sleep is poor or it indicates the presence of sleep disorders; if the final score is equal to 5 or lower, the quality of sleep is good. ${ }^{7-8}$

The following question was then asked: "how has your sleep been here in hospital?" Shortly after, the VSH was applied to assess the quality of sleep in the last 24 hours, that is, the sleep of the aged in hospital. This scale is composed by 16 items ( 15 self-reported items and 1 that is the sum of the first two). Each item consists of statements with opposed meanings written at each end of a $100 \mathrm{~mm}$-long straight line, divided into $5 \mathrm{~mm}$ pieces. The person must draw a perpendicular line to the straight line, where they find the point that expresses the best their situation. ${ }^{9}$ It comprehends three scales - Disorder (seven items, possible variation from 0 to 700), Effectiveness (five items, possible variation from 0 to 600 , as one of the items is the sum of two others) and Supplementation of sleep (four items, possible variation from 0 to 400 ). The values of each scale must be taken into account separately for analysis, i.e., there is not a value for all three together. The higher the score obtained in the Disorder and Supplementation scales the poorer the quality of sleep; as for Effectiveness, a higher score indicates a better quality of sleep. ${ }^{9}$
Initially, a pilot study was carried out for a month, in which adaptations were done regarding inclusion and exclusion criteria, and an open question was introduced concerning the quality of sleep of the aged in hospital. During this period of time, eight samples were collected. After the adaptations were made, the research itself began.

The researching student went to the hospitalization units and after introducing herself to the nurse in charge, she identified the hospitalized patients who met the inclusion criteria. The aged patients were approached in their room and their privacy was respected; a Free and Informed Consent Form was read and signed by them.

Afterwards, the Sociodemographic questionnaire and the PSQI were applied. Then the researching student asked them about their sleep in the hospital, wrote the answers down and applied the VSH.

The researching student read the instruments along with the aged people, in order to help them understand, and they indicated the answers, which she wrote down. This was necessary because although many of them could read, they often had low visual acuity and did not wear glasses.

The research proposal was approved by the Research Ethics Committee of the Faculty of Medical Sciences of the State University of Campinas (Unicamp) on June 29th 2011, under protocol number 512/2011. The aged people who agreed to participate followed the reading and signed the Free and Informed Consent Form, prepared in compliance with the rules of Resolution 196/96 of the Health Council of Brazil. A copy of the Informed Consent Form was handed over to patients and another one was kept by the researcher.

The data collected were entered in a Microsoft Excel 2007 database and exported to a program called Statistical Package for Social Sciences (SPSS, version 16.0) for analysis. They were analyzed by descriptive statistics, including measures of central tendency and dispersion, and frequency tables with absolute numbers and proportions.

\section{RESULTS}

\section{Characterization of subjects}

The aged people (160) were mostly men $(57.1 \%)$, with a mean age of 69.8 (standard devia- 
tion 7.2 and median 68.2). Regarding the marital status, $66.9 \%$ were married, $21.3 \%$ widowers, $6.9 \%$ divorced and $5 \%$ single. They had a mean education level of 4.8 years (standard deviation 4.2 , median 4 years). At the time, $4.4 \%$ were smokers and $16.9 \%$ were drinkers, out of which $77.8 \%$ drank beer. As for physical exercise, $23.1 \%$ practiced it at a mean of five days a week (standard deviation 2.4 and median 7.0), and walking was the most practiced activity.

A total of $35 \%$ were living with their partner only, 30\% with partner and children, $19 \%$ with children, $10 \%$ were living alone and 5.6\% with relatives. They lived with a mean of 1.8 people (standard deviation 1.5 and median 1.0), 55\% slept with their partner, $40.6 \%$ alone and $4.4 \%$ with other people, with a mean of 0.6 people with whom they shared a room (standard deviation 0.5 and median 1.0). 36.9\% reported something that affected their sleep at home, out of which $42.4 \%$ mentioned intrinsic factors as the cause (loneliness, nervousness, worries, poor quality sleep and illnesses, for instance) and for $57.6 \%$ extrinsic factors (noise, brightness, among others) were the cause.

Regarding the use of medications, $88.8 \%$ made continuous use of medicine, with prevalence of anti-hypertensive drugs (91 patients), antihyperglycemic agents (34), diuretics (31) and hypolipidemic agents (29). The use of sleep medicines in the month prior to the research was reported by $23.13 \%$ of patients. The most frequent causes of hospitalization came from disorders of the circulatory system $(38.75 \%)$ and from neoplasms $(28.12 \%)$.

All participants made use of medicine in the hospital, the most used being painkillers and antipyretics (143 prescriptions), laxatives (141 prescriptions), intravenous solutions (102 prescriptions) and medicines for peptic ulcer and gastroesophageal reflux diseases (78 prescriptions). In $23.76 \%$ of the prescriptions, there were anxiolytics, but only $8.13 \%$ of the aged people took them both at home and in hospital. As observed, $15.62 \%$ started the use during hospitalization and $15 \%$ of those who took it at home had the prescription discontinued in hospital. The individuals had been hospitalized for a mean period of 74 hours (standard deviation 25 and median 72 hours).

\section{Assessment of the quality of sleep in hospital}

The VSH descriptive analysis, used to assess the quality of sleep of the aged in hospital is shown in table 1. The variation of values was as follows: Disorder Scale, 0 to 606; Supplementation Scale, 0 to 400; andEffectiveness Scale, 72 to 600. The mean values of the Disorder and Supplementation scales are under half of the possible variation (respectively, 0 to 700 and 0 to 400). Regarding the Effectiveness Scale, the mean is over half of the possible variation (0 to 600).

Table 1 - Descriptive analysis of VSH scales with 160 hospitalized aged people in a university hospital in the countryside of the state of São Paulo. Campinas-SP, 2011- 2012

\begin{tabular}{lccc}
\hline \multicolumn{1}{c}{ Scales } & Mean & $\begin{array}{c}\text { Standard } \\
\text { deviation }\end{array}$ & Median \\
\hline Disorder & 294.8 & 199.8 & 288.9 \\
Supplementation & 98.1 & 117.1 & 69.5 \\
Effectiveness & 374.0 & 128.4 & 400.0 \\
\hline
\end{tabular}

Out of the 38 individuals who were using anxiolytics in hospital, $34.2 \%$ had poor quality of sleep regarding the disorder scale, $21.1 \%$ had poor values in the effectiveness scale and $7.9 \%$ had bad results in the supplementation scale. It was observed that $6.3 \%$ had poor results in all three scales.

\section{Assessment of the quality of sleep at home and its components}

The results obtained with PSQI showed that, at home, the aged patients went to bed between $7 \mathrm{pm}$ and 2:30 pm, took between zero to $330 \mathrm{~min}$ utes to fall asleep, woke up after 3 to 12 hours and slept effectively between 2 to 12 hours. The sleep efficiency ranged between 18 to $143 \%$. Values over $100 \%$ were obtained with $12.5 \%$ of the aged patients. The descriptive analysis of these data is shown in table 2 .

The PSQI global score, which represents the sum of all seven components of quality of sleep and was the instrument used to assess the quality of sleep at home, ranged between 1 and 19 points, with a mean of 8 (standard deviation 3.9 
and median 8.0), indicating poor quality of sleep. Among the aged, $69.4 \%$ were defined as having poor quality of sleep (total score over five points) and $30.6 \%$ as having good quality of sleep, according to the PSQI.

Table 2 - Characteristics of sleep of $\mathbf{1 6 0}$ hospitalized aged people in a university hospital in the countryside of the state of São Paulo. Campinas-SP, 2011- 2012

\begin{tabular}{lccc}
\hline \multicolumn{1}{c}{ Variables } & Mean & $\begin{array}{c}\text { Standard } \\
\text { deviation }\end{array}$ & Median \\
\hline Bed time & $9: 49 \mathrm{pm}$ & $66.0 \mathrm{~min}$ & $10 \mathrm{pm}$ \\
Latency & $38.4 \mathrm{~min}$ & $61.2 \mathrm{~min}$ & $15.0 \mathrm{~min}$ \\
Wake up time & $06: 45 \mathrm{am}$ & $83.0 \mathrm{~min}$ & $06: 30 \mathrm{am}$ \\
Sleep duration & 6.8 hours & 2.0 hours & 7.0 hours \\
Sleep efficiency & $79.4 \%$ & $22.7 \%$ & $83.0 \%$ \\
\hline
\end{tabular}

The analysis of each PSQI component (which can range between zero and three points) was done separately and is shown in table 3 .

Table 3 - Descriptive analysis of PSQI components of $\mathbf{1 6 0}$ hospitalized aged people in a university hospital in the countryside of the state of São Paulo. Campinas-SP, 2011- 2012

\begin{tabular}{lccc}
\hline \multicolumn{1}{c}{ Components } & Mean & $\begin{array}{c}\text { Standard } \\
\text { deviation }\end{array}$ & Median \\
\hline Quality of sleep & 1.2 & 0.6 & 1.0 \\
Sleep latency & 1.4 & 1.0 & 1.5 \\
Night sleep duration & 1.0 & 1.1 & 1.0 \\
Sleep efficiency & 1.3 & 1.3 & 2.0 \\
Night sleep disorders & 1.5 & 0.6 & 1.0 \\
Sleep medicine & 0.7 & 1.2 & 0.0 \\
Daytime sleepiness & 0.9 & 1.0 & 0.5 \\
\hline
\end{tabular}

The factors indicated more frequently as the cause of sleep disorders, according to the PSQI, were: waking up at night or waking up prematurely $(80 \%)$, nocturia $(77.5 \%)$ and pains $(33.1 \%)$. Other factors such as snoring and coughing were occasionally reported (13.1\%).

Cronbach's alpha, used to analyze the internal consistency of PSQI, was 0.659.

The open questions regarding the subjective perception of the aged concerning the quality of sleep at home and in hospital revealed that $62.5 \%$ of the aged patients reported to sleep "well" at home. Out of these, $43.8 \%$ reported to have poor quality of sleep in hospital and $18.8 \%$ to have good quality of sleep in both places. Out of those who reported to have poor quality of sleep at home (36.9\% of patients), $28.1 \%$ stated that the sleep was "good" in hospital and 8.8\% stated that sleep was still "bad" during hospitalization.

\section{DISCUSSION}

In this study, the mean score obtained in VSH, regarding the Disorder and Supplementation scales, was under half of the possible variation, and for the Effectiveness scale, this score was higher. These findings suggest a satisfactory quality of sleep and moderate daytime sleepiness during hospitalization for most of the aged people studied. Nevertheless, the majority $(69.4 \%)$ was defined as having poor quality of sleep at home, according to the PSQI assessment.

The participants were mostly men (57.1\%), differing from the aged population in Brazil, which is composed mostly by women (55.8\%). ${ }^{1}$ This may be due to biological and cultural differences between the genders. Men complain less when it comes to health, because of that stereotype of the "healthy male body", resulting in low demand for health services. This can result in the need for a more intensive treatment, requiring hospitalization. ${ }^{11}$

Concerning the disorders that affect the aged, besides the importance of their origin, attention must be given to their chronic nature as well. ${ }^{12}$ This was confirmed by the data of the present study, as the most frequent reason for hospitalization was circulatory system disorders, followed by neoplasms. According to other studies, 53.3\% of the aged people in Brazil are hypertensive, and although they represent $2.5 \%$ of morbidity, neoplasms are the cause of $16.9 \%$ of deaths of Brazilian aged people ${ }^{1}$, which justifies the need for hospitalization.

The large number of chronic diseases leads to a continuous medication. ${ }^{1}$ Out of the aged people who made use of medicine, $88.8 \%$ did it at home, whereas $100 \%$ had a medical prescription for continuous use during hospitalization.

Habits like physical exercises have an effect on sleep and the aged person's health. ${ }^{13}$ Among the 
interviewees, $23.1 \%$ reported that they do physical exercise, and the most practiced activity was walking, with a mean frequency of five times a week. The practice of physical exercise at some point in life was reported by $21.9 \%$, although they stopped because of the illness itself, among other reasons. This sedentary trend can also be explained by the increase of the functional disability of the elder, which affects the ability to walk.

Thinking about the quality of sleep of the elder, it is important to question them about the regular practice of physical exercise, as this is known to improve the quality of sleep, especially in cases of circadian rhythm disruption. ${ }^{14}$

Regarding the quality of sleep during hospitalization, the results were better than expected, as another study pointed that hospitalization has a negative effect on quality of sleep due to intrinsic and extrinsic factors. ${ }^{14}$ In the VSH, the means of Disorder (under 300), Supplementation (under 100) and Effectiveness (over 300) scales suggest a satisfactory quality of sleep and moderate daytime sleepiness. Despite this, these parameters must be improved, also considering that they might result from sleep medicine intake during hospitalization, which can have immediate consequences and also after discharge.

Daytime sleepiness can be caused by a sleep disorder and by the use of medicine. ${ }^{5}$ The change in the sleep pattern, in this case the poor quality of sleep at night and daytime sleepiness, can make the medicine prescription necessary, such as hypnotics, with a risk of iatrogenic effects. We must remind that hypnotics can lead to addiction. ${ }^{15}$ It is important to underline that $15.62 \%$ of the aged people who had not been using anxyolitics at home had a prescription in hospital.

In a study with 100 adults (mean age 75) hospitalized in a general hospital in Canada, the values obtained with the VSH showed a quality of sleep slightly poorer when compared to the present study, which was expressed by higher scores of the Disorder scale (around 350), similar scores in the Supplementation scale (around 100) and slightly lower in the Effectiveness scale (around 300). ${ }^{16}$ Out of these patients, $31 \%$ made use of some kind of sedative at home in order to sleep and kept it in hospital, and 29\% began to use this medicine in hospital. ${ }^{16}$

The quality of sleep may be associated with adverse effects of medicines, or maybe to the fact of being taken care of, which can reduce worries and result in peacefulness that improves the quality of sleep. But a more consistent statement concerning this topic is beyond the scope of this study, as the factors that resulted or not in a satisfactory quality sleep during hospitalization were not investigated, which can be considered as a limitation of this study.

In another national study carried out with 52 adult patients, $42.3 \%$ assessed subjectively the quality of sleep and considered it as "good" in hospital, and credited it to the possibility of sleeping during the day. According to the authors, this assessment reveals an association between quality and quantity; in other words, to sleep "a lot" means to sleep "well". This is opposed to the findings of the same study, according to which $5.8 \%$ of patients stated not to have woken up during the night, that is, daytime sleep could be associated with night sleep fragmentation. Most of these patients say they sleep better at home than in hospital, and they do not see sleep changes as a problem. ${ }^{17}$

Regarding the quality of sleep at home, assessed with the PSQI, $69.4 \%$ of the aged people were defined as having poor quality of sleep, a figure that shows how important it is to include this point in the routine evaluation. This number was very similar to the one found in a study with aged people with peripheral vascular diseases, in which $70 \%$ of patients had a poor quality of sleep result in the general score with this instrument. ${ }^{18}$

In this study, the PSQI components with higher scores were night sleep disorders, sleep onset latency, sleep efficiency and quality of sleep (in descending order). The component that assesses night sleep disorders includes factors that indicate sleep fragmentation, such as nocturia and pains, as well as difficulty to remain asleep without any apparent reason and waking up prematurely. As a consequence, the sleep efficiency is reduced, which was evidenced in this study. All of these factors represent common complaints among aged people, as well as the difficulty to fall asleep, assessed in this study by the Sleep Onset Latency component. ${ }^{9}$ Hence, the quality of sleep is pointed out as poor, as it does not meet the needs of a quality rest in this age group, which increases the risks of adverse effects.

Sleep deprivation has proved to be a factor bearing considerable risk of falling in patients with 
this diagnosis, which was found in $20 \%$ of men and $36.8 \%$ of women, an expressive number when we consider hospitalized aged people and the social and financial impacts that falls can bring about. ${ }^{19}$ Therefore, the role of the nurse is essential in the identification of nursing diagnoses related to sleep.

Nocturia has risk factors such as age, menopause, chronic diseases, the use of medicine and weak musculature of the pelvic floor, among others, which can result in sleep disorders as it increases the need for voiding more than once during the night. ${ }^{20}$

Studies credit to nocturia in aged people the fact that most of them have a previous chronic disease, called systemic hypertension. The treatment for this disease requires the use of medication that changes the body functioning, resulting in nocturia, for instance, due to the action mechanism of the drug, to drug interactions or even to the lack of information on how to take them, as most aged people have low educational levels. ${ }^{21}$ Another factor that contributes to nocturia is urinary incontinence, as it was observed in another study that $63.3 \%$ of patients with such disorder stated that they did not have a good quality of sleep and $23.3 \%$ of aged women had excessive daytime sleepiness. ${ }^{20}$

Reports of sleep fragmentation (waking up at night and going back to sleep or not) and difficulty to fall asleep were found out among the complaints related to sleep in another study carried out in Brazil with 158 aged people living in the community, but in a lower frequency when compared to our study. ${ }^{22}$ Among the most frequent complaints the authors found snoring, ${ }^{22}$ which was low in our study. Worthy of note that both studies indicate a high prevalence of unsatisfactory quality of sleep at home, having sleep fragmentation as the main reason for it.

In a study carried out with aged Chinese people, $49 \%$ had scores of poor quality of sleep in the PSQI, the main causes for sleep disorders being nocturia $(78 \%)$, their own snoring or their partners' $(19 \%)$ and nightmares $(19 \%){ }^{22}$ In this Chinese study, $22 \%$ of the aged people made use of psychoactive drugs at least once a week, ${ }^{23} \mathrm{a}$ similar percentage showed in our study, in which $23.3 \%$ of people reported this fact. It was observed that despite possible cultural differences between populations, unsatisfactory sleep is present in age groups over 60 years old, which emphasizes the extent of the problem, requiring thus a thorough knowledge in order to implement effective measures by health professionals.

Despite the results found after the analysis of the PSQI, which indicated the prevalence of poor quality sleep at home, $62.5 \%$ of people surveyed reported a "good" quality of sleep. In another study, this contradiction was also observed, suggesting that this discrepancy in the assessment is characteristic of the aged. ${ }^{24}$ In that sense, it is seen that sleep fragmentation, which is the main cause for poor quality of sleep, is often considered as "normal" both by the aged people and the health professionals who care for them.

\section{CONCLUSIONS}

The results of this study show that most of the 160 aged people had satisfactory quality of sleep in hospital and moderate daytime sleepiness, according to the VSH.

Nevertheless, according to the PSQI, almost $70 \%$ of individuals had poor quality of sleep at home, where they slept 6.8 hours on average, with average latency of 38.4 minutes and $79.4 \%$ of sleep efficiency. These figures suggest that, despite the adequate sleep duration at home, sleep fragmentation affects its quality. This feature may be seen as natural for the participants, as a considerable number of people reported having good quality of sleep at home, according to the subjective assessment.

It was not possible to obtain the detailed characteristics of sleep in hospital with the VSH, which is a limitation.

The participation of the nurse in the promotion of sleep quality of aged people is essential and includes all health professionals, from public health to intensive care.

In this study, the indicators of poor quality of sleep at home highlight the need for a detailed assessment of sleep, with particular attention to the causing factors of its fragmentation. This approach can be taken by the nurse who works in public health, both in individual consultations and with groups of aged people and other groups that are known to have sleep disorders, such as hypertensive and diabetes patients.

In hospital, efforts must be made to improve the quality of sleep, with minimal use of sedative 
drugs, for the risks they present to aged people.

The nurse can search in the literature for other non-pharmacological resources that contribute to improve the quality of sleep. In the case of aged people, it is also possible to adapt the schedule of some medicines such as diuretics; to take into account the sustained elimination of some drugs resulting from physiological changes that occur with aging, and the risks of side effects that impair sleep.

Many strategies that can be implemented by the nurse are found in literature, and they must be tested in order to assess their actual effectiveness. Likewise, more thorough studies are necessary to identify factors associated with quality of sleep in hospital, which can foster new practices that result in good quality of sleep during hospitalization, as this is essential for the patient's recovery.

\section{REFERENCES}

1. Ministério do Planejamento, Orçamento e Gestão (BR). Instituto Brasileiro de Geografia e Estatística. Síntese de indicadores sociais. Uma análise das condições de vida da população brasileira. Rio de Janeiro (RJ): MP; 2010.

2. Borges SM, Aprahamian I, Radanovic M, Forlenza OV. Psicomotricidade e retrogênese: considerações sobre o envelhecimento e a doença de Alzheimer. Rev Psiquiatr Clín. 2010; 37(3):131-7.

3. Ferreira OGL, Maciel SC, Costa SMG, Silva AO, Moreira MASP. Envelhecimento ativo e sua relação com a independência funcional. Texto Contexto Enferm [online]. 2012 [acesso 2012 Dez 18]; 21(3):5138. Disponível em: http://www.scielo.br/pdf/tce/ v21n3/v21n3a04.pdf

4. Missildine K, Bergstrom N, Meininger J, Richards K, Foreman MD. Sleep in hospitalized elders: a pilot study. Geriatric Nursing. 2010; 31(4):263-71.

5. Alves-Júnior DR. Repercussão do sono sobre o trabalho. Diagn Tratamento. 2010; 15(3):150-2.

6. North American Nursing Diagnosis Association International. Diagnósticos de Enfermagem da NANDA-International. Definições e classificação. 2012-2014. Porto Alegre (RS): Artmed; 2013.

7. Buysse DJ, Reynolds CF, Monk TH, Berman SR, Kupfer DJ. The Pittsburgh Sleep Quality Index: a new instrument for psychiatric practice and research. Psychiatric Res. 1989; 28(2): 193-213.

8. Bertolazi NA, Fagondes SC, Hoff LS, Dartora EG, Miozzo IC, Barba ME, et al. Validation of the Brazilian Portuguese version of the Pittsburgh Sleep Quality Index. Sleep Medicine. 2011; 12(1):70-5.

9. Bergamasco EC, Cruz DALM. Adaptação da Visual Analog Sleep Scales para a língua portuguesa. Rev
Latino Am Enferm [online]. 2007 [acesso 2012 Set 10]; 15(5):123-9. Disponível em: http:/ / www.scielo. br/pdf/rlae/v15n5/pt_v15n5a17.pdf

10. Snyder-Halpern R, Verran JA. Instrumentation to describe subjective sleep characteristics in healthy subjects. Res Nurs Health. 1987; 10(3):155-63.

11. Costa-Júnior FM, Maia ACB. Concepções masculinas sobre gênero e saúde. Psicol Teor Pesqui. 2009; 25(1):55-63.

12. Nasri F. O envelhecimento populacional no Brasil. Einstein. 2008; 6(Supl 1):S4-6.

13. Leite-Cavalcanti C, Rodrigues-Gonçalves MC, Rios-Asciutti LS, Leite-Cavalcanti A. Prevalência de doenças crônicas e estado nutricional em um grupo de idosos brasileiros. Rev Salud Pública. 2009; 11(6):865-77.

14. Costa SV, Ceolim MF. Fatores que interferem na qualidade do sono de pacientes internados. Rev Esc Enferm USP. 2013 Jul-Set; 47(1):46-52.

15. Santos JC, Ceolim MF. Iatrogenias de enfermagem em pacientes idoso hospitalizados. Rev Esc Enferm USP. 2009 Dec; 43(4):810-7.

16. Frighetto L, Marra C, BandaliS, Wilbur K, Naumann $\mathrm{T}$, Jewesson P. An assessment of quality of sleep and the use of drugs with sedating properties in hospitalized adult patients. Health Qual Life Outcomes. 2004; 2: 17.

17. Silva LEL, Oliviera MLC, Inaba WK. Fatores que interferem na qualidade do sono de pacientes internados. Rev Eletr Enferm [online]. 2011 [acesso 2012Set 12]; 13(3). Disponível em: http:/ / www.fen. ufg.br/revista/v13/n3/pdf/v13n3a18.pdf

18. Corrêa C, Ceolim MF. Qualidade do sono em pacientes idosos com patologias vasculares periféricas. Rev Esc Enferm USP. 2008; 42(1):12-8.

19. Machado TR, Oliveira CJ, Costa FBC, Araujo TL. Avaliação da presença de risco para queda em idosos. Rev Eletr Enf [online]. 2009 [acesso 2012 Set 15]; 11(1). Disponível em: http:/ / www.fen.ufg.br/ fen_revista/v11/n1/pdf/v11n1a04.pdf

20. Fonseca DC, Galdino DAA, Guimarães LHCT, Alves DAG. Avaliação da qualidade do sono e sonolência excessiva diurna em mulheres idosas com incontinência urinária. Rev Neurocienc. 2010; 18(3):294-9.

21. Vasconcelos FF, Victor JF, Moreira TMM, Araújo TL. Utilização medicamentosa por idosos de uma Unidade Básica de Saúde da Família de FortalezaCE. Acta Paul Enferm. 2005; 18(2):178-83.

22. Oliveira BH, Yassuda MS, Cupertino AP, Neri AL. Relações entre padrão do sono, saúde percebida e variáveis socioeconômicas em uma amostra de idosos residentes na comunidade - Estudo PENSA. Ciênc Saúde Coletiva. 2010; 15(3):851-60.

23. Wu CY, Su TP, Fang CL, Yeh Chang M. Sleep quality among community-dwelling elderly people and its 
demographic, mental, and physical correlates. J Chin Med Assoc. 2012 Fev; 75(2):75-80.

24. Mansano-Schlosser TC, Ceolim MF. Fatores associados à qualidade do sono de idosos submetidos à quimioterapia. Rev Latino-Am Enferm [online]. 2012 [acesso 10 Out 2013]; 20(6). Disponível em: http://www.scielo.br/pdf/rlae/v20n6/pt_12.pdf

Faculdade de Enfermagem - Universidade Estadual de

Campinas

13083-887 - Campinas, SP, Brasil

E-mail: fceolim@fcm.unicamp.br 